\title{
THE RESULTS OF ANTERIOR CRUCIATE LIGAMENT RECONSTRUCTION WITH AUTOGENOUS HAMSTRING TENDONS
}

\author{
Karslioglu Bulent, ${ }^{1}$ Erdem Yusuf, ${ }^{2}$ Tekin Ali Cagri, ${ }^{1}$ Tekin Esra, ${ }^{3}$ Tunay Servet ${ }^{2}$ \\ ${ }^{1}$ Okmeydani Training and Research Hospital Department of Orthopedics and Traumatology, Istanbul, Turkey \\ ${ }^{2}$ Department of Orthopedics and Traumatology, Gulhane Training and Research Hospital, Ankara, Turkey \\ ${ }^{3}$ Okmeydani Training and Research Hospital Department of Anesthesiology, Istanbul, Turkey
}

Primljen/Received 15. 01. 2019. god.

Abstract: Introduction: Anterior cruciate ligament (ACL) injuries are the most common type of injury among knee ligament injuries. Despite the high success rates at ligament reconstruction with arthroscopic techniques, efforts for choosing the best grafts and fixation materials and appropriate post-operative rehabilitation are still ongoing. Materials and Methods: Between January 2007 and December 2010, 105 patients who underwent arthroscopic anterior cruciate ligament reconstruction using autogenous hamstring tendons were included in our study. The mean follow-up time was 16.3 months (7-46 months). The patients were evaluated according to physical examination findings like Lachman tests, Pivot-Shift, anterior drawer tests, thigh circumference measurement and clinical scores like Lysholm, IKDC score and VAS scores. Results: All patients underwent arthroscopy using standard arthroscopy portals. The residues of the ACL were cleaned and notchplasty was performed, and the semitendinosus and grasilis tendons were placed with transtibial technique in accordance with the trace of the natural ACL.

Preoperatively, the Lysholm score was $56.16 \pm$ 17.4 and postoperatively, the score was $90.16 \pm 6.6$ and the result was statistically significant. Lachman was found to be $86.7 \%$ negative, pivot shift was $100 \%$ negative and the anterior drawer test was $95.2 \%$ negative. Preoperative VAS was $6.28 \pm 1.9$ and postoperative VAS was $3.41 \pm 1.2$. According to the IKDC score, $4,8 \%$ of the patients were A, $41 \% \mathrm{~B}, 41,9 \% \mathrm{C}$ and $12,4 \% \mathrm{D}$ groups, $54,8 \%$ of the patients in the postoperative evaluation. A, $36.2 \% \mathrm{~B}, 8.6 \% \mathrm{C}$ and $1 \% \mathrm{D}$ groups. $12 \%$ of the patients felt numbness around the graft site. No other complication was observed. Conclusion: When ACL surgery with hamstring tendons is performed with appropriate surgical technique, satisfactory results are obtained. Anterior knee pain and pa-
Prihvaćen/Accepted 01. 03. 2019. god.

tella-related complications are frequently seen at patellar tendon grafts. This problem can be a reason for the preference of hamstring tendons in ACL repairs.

Key words: anterior cruciate ligament; reconstruction; hamstring; rehabilitation.

\section{INTRODUCTION}

The number of knee-related injuries are increasing nowadays due to the increase in sports awareness. Anterior cruciate ligament (ACL) injuries are the most common type of injury among knee ligament injuries. The efforts to make the diagnosis goes back to the years before Christ in the historical development. Until today's modern techniques many different surgical methods which began in the 1800's has been used in this type of injury.

Despite the high success rates at ligament reconstruction with arthroscopic techniques, efforts to achieve better understanding the etiological factors, choosing the best grafts and fixation materials and appropriate post-operative rehabilitation are still ongoing.

In this study, we aimed to evaluate the results of anterior cruciate ligament reconstruction with hamstring autogenous grafts according to the current literature.

\section{MATERIAL AND METHODS}

Between January 2007 and December 2010, a total of 112 patients underwent anterior cruciate ligament reconstruction. 7 patients were reconstructed with allografts and other 105 patients underwent arthroscopic anterior cruciate ligament reconstruction with autograft hamstring tendons. 105 patients with autogenous hamstring tendon graft were included in our study.

An informed consent form was signed by all patients. All patients included in the study were treated 
Table 1. Preoperative physical examination results

\begin{tabular}{|l|c|c|}
\hline \multicolumn{1}{|c|}{ PRE-OP } & SCORE & PERCENT \\
\hline \multirow{3}{*}{ LACHMAN } & +1 & $\% 72,4$ \\
& +2 & $\% 22,9$ \\
& +3 & $\% 2,9$ \\
\hline \multirow{2}{*}{ PIVOT-SHIFT } & Positive & $\% 94,3$ \\
& Negative & $\% 5,7$ \\
\hline \multirow{3}{*}{ ANTERIOR DRAWER } & +1 & $\% 85,7$ \\
& +2 & $\% 13,3$ \\
& +3 & $\% 1$ \\
\hline
\end{tabular}

with endo-button method. $96.8 \%$ of the patients were male and $3.2 \%$ were female. $61 \%$ of the knees were right and $39 \%$ were left. The mean age was $28.76 \pm 6,3$ (16-43) years. The period between the anterior cruciate ligament injury and surgery was $13.3 \pm 8.2$ months (15 days-48 months). In the etiology of ACL, non-contact injuries were found to be $54.2 \%$, contact injuries were $41 \%$, and at $4.8 \%$ of the patients the etiology was not fully demonstrated.

The diagnosis was made with physical examination findings and radiological evaluation in all patients. Lachman and Pivot-shift tests were performed on physical examination (Table 1). Direct radiography and magnetic resonance imaging were taken. The mean follow-up was 16.3 months (7-46 months).

\section{Surgical Technique}

All patients were given $1 \mathrm{~g}$ cefazolin intravenously for infection prophylaxis one hour before the operation. Patients were re-examined under anesthesia and clinical diagnosis was confirmed. Standard anterolateral, anteromedial portals were used. ACL and posterior cruciate ligament were examined. It was confirmed by the probe that the ACL was injured. ACL residues were removed with shaver. The femoral attachment of the ACL was revealed by making notchplasty. Then, arthroscopic procedure was interrupted, and grafting was started.

3 to $4 \mathrm{~cm}$ longitudinal incision was made from 1 $\mathrm{cm}$ medial of the tuberositas tibia and 3 to $4 \mathrm{~cm}$ below the medial joint space- gracilis tendon were palpated-to get hamstring autograft. Sartorial fascia was reached and cut. The sartorius tendon was located at the forefront under the sartorius fascia. Semitendinosus and gracilis tendons were followed from distal to proximal. Semitendinosus and the gracilis tendons were separated from the surrounding tissues and cut from the adhesion sites. Both tendons were sutured and marked. The tendon was passed through the tendon scraper and held with Kocher pens then the stripper was advanced with repetitive maneuvers until the tendon was pulled out. The long and thick tendon is placed outside, and the two tendons are intertwined and attached to each other with $2 / 0$ rapid vicryl. Krackow sutures were thrown using ethibond from approximately $2 / 3$-part of each end when the tendons were stretched with the special stretching apparatus. A guide wire was sent from the anteromedial portal when $55^{\circ}$ adjusted tibial guide was located to the end of lateral meniscus posterior horn and $7 \mathrm{~mm}$ anterior of the ACL attachment. The tibial tunnel was opened over the guide tibial wire taking care of the thickness of the graft. For femoral tunnel, when knee was at $90^{\circ}$ flexion, femoral aimer with a diameter appropriate to graft thickness was placed to posterior cortex of the intercondylar notch for right knee 11 clockwise and for left knee 1 clockwise with transtibial technique. The guide wire sent through the aimer was removed from the femoral anterior cortex. The knee was kept constant at $90^{\circ}$ flexion to prevent damage to the guide wire. Femoral drill was sent over the guide wire according to the length of the graft desired to remain in the tunnel (average $25-35 \mathrm{~mm}$ ). The endobutton drill was then advanced until the femoral anterior cortex was passed. The length of the endobutton tunnel was subtracted from the length of the femoral tunnel length and $5 \mathrm{~mm}$ endobutton length added to calculate appropriate endobutton size to be used. Endobutton free ends with attached graft were pushed through the hole in the back of the guide wire. The guide wire was pulled from the anterior cortex of the femur to allow the graft to enter the femoral tunnel. Four endobutton threads ( 2 in 2 different colors) were taken together with the guide wire from the femoral anterior cortex and the endobutton was placed in the femoral anterior cortex. Fixation was checked by pulling the graft from the tibial side. An interference screw and/or biodegradable screw were used for the tibial fixation. The knee was fixed to the tibia with interference screw while the knee was flexed $20^{\circ}$. Jones bandage was applied to the knee in full extension. After the operation, continuous ice was applied to the knee and 24 hours later the drain was pulled. Quadriceps exercises and exercises with CPM device were started in early period.

\section{RESULTS}

Medial meniscus rupture at 26 patients (24.8\%), at 18 patients $(17.1 \%)$ lateral meniscus and at 5 patients $(4.8 \%)$ concomitant medial and lateral meniscus tears was observed and therefore partial meniscectomy was performed. There was chondral lesion in femoral medial condyle at 8 patients $(7,6 \%)$.

The upper pole of the thigh was measured from the proximal $15 \mathrm{~cm}$ of the patella upper pole and compared with the postoperative third month measurements. T-test 
Table 2. The results of the patients were evaluated statistically according to the results of the 12 th month

\begin{tabular}{|l|c|c|}
\hline POSTOPERATIVE & SCORE & PERCENTAGE \\
\hline \multirow{2}{*}{ LACHMAN } & Negative & $\% 86,7$ \\
& +1 & $\% 12,4$ \\
& +2 & $\% 1$ \\
\hline PIVOT-SHIFT & Negative & $\% 100$ \\
\hline ANTERIOR & Negative & $\% 95,2$ \\
DRAWER & +1 & $\% 4,8$ \\
\hline
\end{tabular}

Table 3. IKDC scoring were performed at12 months

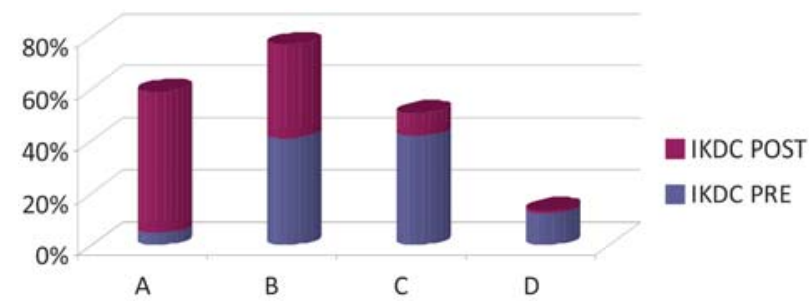

was performed for the evaluation of thigh circumference measurement which was evaluated as a dependent group that conforms to the normal distribution. The mean preoperative thigh circumference was $45.37 \mathrm{~cm}$ and the post op thigh circumference was $43.35 \mathrm{~cm}$. This result was statistically significant $(\mathrm{p}<0.001)$.

The mean follow-up was 16.3 months (7-46 months). Lysholm and IKDC scoring were performed at 3-6 and 12 months. Lysholm scores in two dependent groups that did not conform to normal distribution were evaluated according to Wilcoxon test., Lysholm score was $56.16 \pm 17.4$ preoperatively and the postoperative score was $90.16 \pm 6.6$ and the result was statistically significant $(\mathrm{p}<0.001)$. Pre- and postoperative VAS (Visual Analogue Scale) were performed. Preoperative VAS was $6.28 \pm 1.9$ and postoperative VAS was $3.41 \pm 1.2$. Lachman, Pivot-shift and Forward Drawer tests were performed at 3-6 and 12 months postoperatively. The results of the patients were evaluated statistically according to the results of the 12th month (Table 2). According to the International Knee Documentation Committee Evaluation Form (IKDC), $4,8 \%$ of the patients were included in the A group, $41 \% \mathrm{~B}$ group, $41,9 \% \mathrm{C}$ group and $12,4 \% \mathrm{D}$ groups. At postoperative evaluation (when the results of the 12th month of all patients were evaluated to ensure standardization), $54.3 \%$ of the patients were in A group, $36.2 \% \mathrm{~B}$ group, $8.6 \% \mathrm{C}$ group and $1 \% \mathrm{D}$ groups (Table 3 ).

\section{DISCUSSION}

The ACL lesion is the most common ligament injury among sports-related knee ligament injuries (1). The ACL injury mechanism may be sports-related or traumatic. Sports-related causes are also referred as non-contact injuries. In our study, the rate of non-contact injuries was $54.3 \%$ and the traumatic injuries was $41 \%$.

There are still controversial issues in ACL surgery that have not been fully resolved. Discussion on the graft to be used in ACL reconstruction is ongoing. The ideal graft to be used should be easily accessible and easy to take, must be similar to natural ligament, and be able to allow aggressive rehabilitation. The graft should rapidly gain anatomical characteristics, should not cause morbidity in the donor field, should not cause disease transition or immune response. It should also not be expensive (2).

The graft is characterized by two anatomical features: Strength and stiffness. The strength of the graft should be equal to or greater than the natural ACL strength. The most commonly used autografts in ACL surgery are hamstring tendons and bone-patellar tendon-bone (BPB) grafts. Noyes et al in their study on BPB graft showed that the $14 \mathrm{~mm}$ wide graft's strong was $164 \%$ of normal ACL, and $10 \mathrm{~mm}$ B graft' s strong was $107 \%$ of normal ACL strength. In the same study, they have reported that a single semitendinosus-free graft's (ST) strong was $70 \%$ of normal ACL, single gracilis grafts' strong $(\mathrm{G})$ was $50 \%$ of normal ACL, double ST/G graft's strong was $250 \%$ of normal ACL of and quadriceps-patellar retinaculum-patellar tendon graft's strong (QT) was $14-21 \%$ of normal ACL reported $14-21 \%$ strength $(3,4)$.

Another feature of the graft is its stiffness. Insufficiency occurs early in hard grafts and late in soft grafts due to excess energy absorption. Therefore, the stiffness of the graft is important. While BPB is 3-fold harder than normal ACL, ST/G stiffness is equal to normal ACL (4).

Because of their high strength and stiffness and better fixation of bone-bone fixation, BPB grafts were preferred in ACL reconstructions. However, the disadvantages of this grafts are the problems such as anterior knee pain, patellar fracture, patellofemoral crepitation, numbness because of damage to infrapatellar branch of the saphenous nerve and loss of quadriceps strength (5). Since the strength and stiffness of the hamstring tendons were less than the normal ACL, this problem was prevented by forming a quadruple hamstring graft from these tendons.

In hamstring grafts donor site morbidity is less than patellar tendon grafts. Neuromas due to damage to the infrapatellar branch of the saphenous nerve are less common during hamstring graft harvesting. (6).

An interesting fact about the hamstring tendons is that they continue regeneration after the harvesting of these tendons.Ferretti et al. (7) showed in their study radiological signs of fibrous bands began to form in the remaining tendon path after removal of semitendinosus tendon.

In recent years, fixation of grafts to allow early rehabilitation of patients gained importance. The most com- 
monly used fixation device for hamstring tendon fixation is endobutton. It has been shown that the endobutton fixation force is stronger than the interference screw. Endobutton transfers the force through the graft to the lateral cortex of the femur. The durability and survival of graft is so prolonged. However, due to the fact that the fixation is far from the joint, there are studies indicate that the endobutton does not prevent the piston movement in the tunnel and may eventually cause tunnel expansion $(8,9,10)$.

The effects ofusing hamstring tendons on knee flexion or internal rotation are still a matter of debate. Hamstring tendons are the primary flexor of the knee andat the same time responsible for the internal rotation of the tibia. Some studies have stated that there is no hamstring weakness in the long term (11), but some studies have reportedmild hamstring weakness $(12,13)$.

Hamstring muscle weakness causes 2 problems. Hamstring muscle weakness first makes rehabilitation difficult after ACL reconstruction.In most rehabilitation programs, hamstring muscles have early and aggressive hamstring strengthening due to the synergistic study with ACL (14) in providing anterior knee stability. Secondly, weakness of hamstring muscles adversely affects athletic performance.

In a study to demonstrate the limitation of motion after the use of hamstring graft (15), postural stability with Biodex Balance system and flexion, extension, internal rotation and external rotation moment indexes and isokinetic extension/flexion moment measurements with Cybex dynamometer were performed. Measurements show that flexion-extension and internal rotation-external rotation forces are reduced in the operated extremity at the postoperative 1st year. This result demonstrates the importance of early and aggressive hamstring strengthening in the postoperative rehabilitation program in patients undergoing reconstruction with hamstring tendon.

There is still controversy about the time of ACL reconstructions. There is a risk of arthrofibrosis in acute reconstructions. Shelbourne (16) reported the rate of arthrofibrosis as $17 \%$ when reconstructed in the first three weeks after injury.On the other hand, this rate was $4 \%$ for those who were operated after three weeks. The rate of arthrofibrosis was decreased from $7 \%$ to $0.5 \%$ with the accelerated rehabilitation program. Waiting for the decrease of the edema and patient's regain mobilityand starting rehabilitation before surgery and reconstruction in the subacute period (4-6 weeks) is recommended (17). In addition, additional meniscus injuries and chondral damage have been reported in chronic repairs. In our study, the time between the patient's ACL rupture time and operation time was found as $13.3 \pm 8.2$ months ( 15 days-48 months).

Proper rehabilitation program after ACL reconstruction is one of the most important steps of treat- ment. This step directly affects the success of surgery. According to the literature results, the average time to return to active sport is 6 months (18). It was stated that early initiation of range of motion(ROM) exercises in early post-operative period and post-operative early mobilization positively affected rehabilitation and prevented quadriceps atrophy (18). We started passive ROM exercises with CPM after removing the drain and Jones bandage for our patients.

Debates on the post-surgery brace usingis also continuing. In a study conducted on healthy ACL volunteers using various brands of brace, none of the braces did not prevent any strain on the ACL in the normal activities of the knee but inhibited the anterior movement of the tibia at high forces and challenging movements (18). Chadwick et al. (19) reported that the use of a brace after the reconstruction using hamstring tendons did not alter clinical outcomes. In a study performed by Beynnon et al. (20) at patients with an ACL lesion and reconstructed ACL lesion, it has been shown that brace contributes to the development of knee proprioception. We applied brace for 6 weeks to the patients in our study.

\section{CONCLUSION}

As a result, if the ACL surgery using hamstring tendons is performed with appropriate surgical technique, satisfactory results may be obtained. The reason for the selection of hamstring tendons at ACL reconstructionsmay be the high incidence of knee pain and patellar complications at BPB grafts.
Abbreviations
ACL - Anterior Cruciate Ligament
IKDC - Score: International Knee Documenta-
tion Committee Score
VAS - Score: Visual Analogue ScaleScore
BPB Graft - Bone-Patellar Tendon-Bone Graft
ST Graft - Semitendinosus-Free Graft's
ST/G Graft - SemitendinosusGracilis Graft
ROM - Range Of Motion

\section{Acknowledgements}

There is no acknowledgements.

\section{Founding}

All authors declare that they have no founding.

\section{DECLARATION OF INTEREST}

The authors declare that there are no conflicts of interest.

\section{Licensing}

This work is licensed under a Creative Commons Attribution 4.0 International (CC BY 4.0) License. 


\title{
Sažetak
}

\section{REZULTATI REKONSTRUKCIJE PREDNJEG UKRŠTENOG LIGAMENTA KOLENA UZ UPOTREBU AUTOGENE TETIVE}

\author{
Karslioglu Bulent, ${ }^{1}$ Erdem Yusuf, ${ }^{2}$ Tekin Ali Cagri, ${ }^{1}$ Tekin Esra, ${ }^{3}$ Tunay Servet ${ }^{2}$ \\ ${ }^{1}$ Okmeydani Training and Research Hospital Department of Orthopedics and Traumatology, Istanbul, Turkey \\ ${ }^{2}$ Department of Orthopedics and Traumatology, Gulhane Training and Research Hospital, Ankara, Turkey \\ ${ }^{3}$ Okmeydani Training and Research Hospital Department of Anesthesiology, Istanbul, Turkey
}

Uvod: Povrede prednjeg ukrštenog ligamenta kolena (ACL) su najčešće među povredama tetiva kolena. Uprkos visokoj stopi uspešnosti u rekonstrukciji pomoću artroskopskih tehnika, problemi oko odabira najboljeg grafta i fiksacionog materijala, kao i adekvatne postoperativne rehabilitacije i dalje postoje. Materijal i metode: Između januara 2007. i decembra 2010. godine izvedena je studija u kojoj je uključeno 105 pacijenata koji su podvrgnuti artroskopskoj rekonstrukciji prednjeg ukrštenog ligamenta koristeći autogene delove tetiva. Prosečna dužina praćenja bila je 16,3 meseca (7-46 meseci). Pacijenti su bili evaluirani na osnovu fizikalnog pregleda pomoću sledećih proba: Lahmanov test, Pivot-Šift, test prednje fioke, kao i pomoću merenja cirkumferencije butine i korišćenjem kliničkog skora kao što je Lysholm, IKDC skor i VAS skor. Rezultati: Svi pacijenti su podvrgnuti artroskopiji koristeći standardne artroskopske portove. Ostaci ACL su uklonjeni i izvedena je notch-plastika, a tetive semitendineusa i gracilisa su postavljene koristeći transtibijalnu tehniku u skladu sa prirodnom anatomskom pozicijom ACL. Preopera-

\section{REFERENCES}

1. Gianotti SM, Marshall SW, Hume PA, Bunt L. Incidence of anterior cruciate ligament injury and other knee ligament injuries: a national population-based study. J Sci Med Sport. 2009; 12(6): 622-7.

2. Hospodar SJ, Miller MD. Controversies in ACL reconstruction: bone-patellar tendon-bone anterior cruciate ligament reconstruction remains the gold standard. Sports Med Arthrosc. 2009; 17(4): 242-6.

3. Noyes FR, Mooar PA, Matthews DS, Butler DL. The symptomatic anterior cruciate-deficient knee. Part I: the long-term functional disability in athletically active individuals. J Bone Joint Surg Am. 1983; 65(2): 154-62.

4. Noyes FR, Matthews DS, Mooar PA, Grood ES. The symptomatic anterior cruciate-deficient knee. Part II: the results of rehabilitation, activity modification, and counseling on functional disability. J Bone Joint Surg Am. 1983; 65(2): 163-74.

5. Fu FH, Bennett CH, Ma CB, Menetrey J, Lattermann C. Current trends in anterior cruciate ligament reconstruction. Part II. Operative procedures and clinical correlations. Am J Sports Med. 2000; 28(1): 124-30.

6. Ejerhed L, Kartus J, Sernert N, Kohler K, Karlsson J. Patellar tendon or semitendinosus tendon autografts for anterior cru- tivno, Lisholm skor bio je $56,16 \pm 17,4$, a postoperativno iznosio je 90,16 $\pm 6,6$. Poređenje ove dve vrednosti pokazalo je statističku značajnost. Lahman je bio u $86,7 \%$ slučajeva negatvan, pivot šift test je bio negativan u $100 \%$ slučajeva, a test prednje fioke bio je u $92,5 \%$ slučajeva negativan. Preoperativni VAS bio je $6,28 \pm 1,9$, a postoperativni VAS bio je $3,41 \pm 1,2$. Prema IKDC skoru, $4,8 \%$ pacijenata bilo je tip A, $41 \%$ tip B, $41,9 \%$ tip C i $12,4 \%$ tip D; $54,8 \%$ pacijenata je u postoperativnoj proceni A, $36.2 \% \mathrm{~B}, 8.6 \% \mathrm{C}$ i $1 \% \mathrm{D}$ grupa. $12 \%$ pacijenata osećalo je utrnulost u predelu grafta. Nijedna druga komplikacija nije primećena. Zaključak: Kada se primeni odgovarajuća hirurška tehnika uz pomoć autogenih delova tetiva kod pacijenata obolelih od ACL, zadovoljavajući rezultati se dobijaju. Bolovi u predelu prednje strane kolena, kao i komplikacije vezane za čašicu se često viđaju kod patelarnog tetivnog grafta. Ovaj problem može da predstavlja razlog zbog kojeg se preferiraju autogeni delovi tetiva ACL.

Ključne reči: prednji ukršteni ligament, rekonstrukcija, rehabilitacija.

ciate ligament reconstruction? A prospective randomized study with a two-year follow-up. Am J Sports Med. 2003; 31(1): 19-25.

7. Ferretti A, Conteduca F, Morelli F, Masi V. Regeneration of the semitendinosus tendon after its use in anterior cruciate ligament reconstruction: a histologic study of three cases. Am J Sports Med. 2002; 30(2): 204-7.

8. Pena E, Calvo B, Martinez MA, Palanca D, Doblare $\mathrm{M}$. Influence of the tunnel angle in ACL reconstructions on the biomechanics of the knee joint. Clin Biomech (Bristol, Avon). 2006; 21(5): 508-16.

9. Howell SM, Hull ML. Checkpoints for judging tunnel and anterior cruciate ligament graft placement. J Knee Surg. 2009 22(2): 161-70.

10. Paessler HH, Mastrokalos DS. Anterior cruciate ligament reconstruction using semitendinosus and gracilis tendons, bone patellar tendon, or quadriceps tendon-graft with press-fit fixation without hardware. A new and innovative procedure. Orthop Clin North Am. 2003; 34(1): 49-64.

11. Lipscomb AB, Johnston RK, Snyder RB, Warburton MJ, Gilbert PP. Evaluation of hamstring strength following use of semitendinosus and gracilis tendons to reconstruct the anterior cruciate ligament. Am J Sports Med. 1982 10(6): 340-2.

12. Marder RA, Raskind JR, Carroll M. Prospective evaluation of arthroscopically assisted anterior cruciate ligament re- 
construction. Patellar tendon versus semitendinosus and gracilis tendons. Am J Sports Med. 1991; 19(5): 478-84.

13. Yasuda K, Tsujino J, Ohkoshi Y, Tanabe Y, Kaneda K. Graft site morbidity with autogenous semitendinosus and gracilis tendons. Am J Sports Med. 1995; 23(6): 706-14.

14. More RC, Karras BT, Neiman R, Fritschy D, Woo SL, Daniel DM. Hamstrings-an anterior cruciate ligament protagonist. An in vitro study. Am J Sports Med. 1993; 21(2): 231-7.

15. Karslioglu B, Erdem Y. Effects on knee kinematics following anterior cruciate ligament repair using semitendinosus and gracilis tendon grafts. Medicine Science International Medical Journal. 2017: 6(2): 310-3.

16. Shelbourne KD, Wilckens JH, Mollabashy A, DeCarlo M. Arthrofibrosis in acute anterior cruciate ligament reconstruc- tion. The effect of timing of reconstruction and rehabilitation. Am J Sports Med. 1991; 19(4): 332-6.

17. Hascelik Z. On capraz bag lezyonu onarimi sonrasi rehabilitasyon. Acta Orthop Traurnatol Turc. 1999; 33: 446-8.

18. Carneiro M, Navarro RD, Nakama GY, Barretto JM, de Queiroz AA, Luzo MV. Arthroscopic anterior cruciate ligament double-bundle reconstruction using hamstring tendon grafts-fixation with two interference screws: technical note. Knee Surg Sports Traumatol Arthrosc. 2009; 17(3): 321-3.

19. Prodromos CC, Han YS, Keller BL, Bolyard RJ. Stability results of hamstring anterior cruciate ligament reconstruction at 2- to 8-year follow-up. Arthroscopy. 2005; 21(2): 138-46.

20. Beynnon BD, Good L, Risberg MA. The effect of bracing on proprioception of knees with anterior cruciate ligament injury. J Orthop Sports Phys Ther. 2002;32(1):11-5.

\section{Correspondence to/Autor za korespondenciju}

Karslioglu Bulent

Okmeydani Training and Research Hospital Department of Orthopedics and Traumatology

Istanbul, Turkey

email: bukars@gmail.com 